\title{
Bill Clinton, Republican Strategy, and the 1994Elections: How Midterms Become Referenda on the President
}

\author{
James D. King \\ University of Wyoming \\ jking@uwyo.edu
}

\begin{abstract}
The surprising 1994 midterm congressional election gave Republicans control of the House of Representatives for the first time in four decades and offers an opportunity to study the dynamics of a referendum on the president. District-level contextual data on Republicans' anti-Clinton campaign themes are used to demonstrate the dynamic of creating a presidential referendum in a midterm election. Making President Clinton a focus of the campaign within the constituency decreased the probability of an individual voter casting a ballot for the Democratic congressional candidate, heightened the impact of Clinton's popularity on individual vote choice; and decreased the aggregate vote percentages for the Democratic candidates. It is unmistakable that highlighting the president's job performance and his policies at the district level transformed the midterm congressional election into a presidential referendum.
\end{abstract}

"Republicans clearly want to run this as a national referendum on Bill Clinton and his policies." - David S. Broder (1994b)

\section{Introduction}

Few election results were more surprising than those of the 1994 midterm congressional election. The 54-seat loss by the Democratic Party in the House of Representatives was the largest change in seats held by a political party in nearly half a century and far exceeded the expectations of most political observers. When asked for their predictions, only three of fourteen scholars and journalists polled by the Washington Post accurately predicted the Republican takeover of the House (Broder 1994c). Earthquake and tidal wave metaphors were common in describing the election outcome. New York Times columnist William Safire (1994) combined the two: "Tsunami is the Japanese word for 'great wave caused by underwater seismic shock.' What was the shock that caused the conservative wave of 1994?" Even House Minority Whip Newt Gingrich, an architect of the Republican campaign strategy and the prospective Speaker of the House, was surprised by the Republicans' gains. President Bill Clinton $(2004,629)$ in his memoirs was blunt in his assessment of what occurred in the midterm election: "On November 8 , we got the living daylights beat out of us."

Republican candidates and leaders were quick to credit the Contract with America, a pledge to bring ten specific proposals to votes in the House of Representatives, as the reason for their successes in 1994. While there is no doubt that the Contract with America represented one

\footnotetext{
${ }^{1}$ See also: Balz (1994a), Berke (1994), Owens (1998), Abramowitz (1995), and Jacobson (1996).
} 
of the leading attempts at establishing responsible party government in the United States, the president remained the central topic of the campaign in many congressional districts. "It's fine for Republicans to talk about positive programs at Washington TV extravaganzas," wrote Washington Post columnist David Broder (1994a) shortly after the Contract was unveiled, "but across the country their candidates seem to be running, not for any policy, but against President Clinton."

The 1994 campaign merits re-examination at its twenty-fifth anniversary. The nature of this campaign provides an opportunity to study midterm elections from the perspective of the strategy of opposition party candidates. The "nationalization" of the congressional campaign is not one of happenstance but one of candidate strategy. As Alan Abramowitz $(1985,33)$ observes, "national issues can become local issues if these issues are raised by the local candidates." This paper uses data from the American National Election Study and district-level contextual data from 1994 to demonstrate that the "presidential referendum" characterization of midterm elections is in part the product of calculated decisions by opposition party candidates. The consequences of candidates making the president and his policies the focus of the campaign at the constituency level are examined. Specifically, making President Clinton a focus of the district-level campaign decreased the probability of a voter casting a ballot for the Democratic congressional candidate and decreased Democratic candidates' vote percentages.

\section{The Midterm Election as a Presidential Referendum}

The loss of 54 House seats by the Democrats in 1994 was the largest for a president's party in a midterm election since 1946. Through 1950s, 1960s, and 1970s, the president's party suffered greater losses in the second midterm election of a party's regime, a pattern that was broken in the 1980s when Republicans lost more seats in 1982 than in 1986. Although unknowable at the time, the 1994 election set up a similar pattern for the Clinton presidency. ${ }^{2}$

Many reasons for the larger-than-expected gains by Republicans have been offered. While Republicans were quick to credit the Contract with America as the reason for their successes in 1994, surveys conducted both before and after the election show extraordinary majorities of Americans were unaware of the Contract. New York Times/CBS News Polls taken in late October and in December showed $71 \%$ and $73 \%$ of respondents, respectively, indicating that they had never heard of the Contract with America (Abramson et al. 1995; Jacobson 1996). Students of American elections looked for other explanations. Campbell (1997a) attributed the surprising Democratic loss to a realignment within the electorate that favors the Republican

\footnotetext{
${ }^{2}$ Democrats gained seats in the House of Representatives in the 1998 election, as the Republican majority pushed for Clinton's impeachment in the face of polls showing a majority of Americans opposed to removing the president. This was the first instance of the presidential party gaining seats in a midterm election since 1934.
} 
Party. ${ }^{3}$ Others contend that Republicans had various advantages concerning key resources particularly having a higher percentage of experienced candidates and having better financed candidates in contested races (Jacobson 1996; Owens 1998). Finally, Jacobson (1996) and Brady et al. (1996) argue that support for Clinton's legislative agenda factored into Democratic incumbents' vote percentages and likelihood of defeat, making the election a referendum on the Clinton presidency. ${ }^{4}$

There is little original in the claim that a midterm election was a referendum on the president. Early in the twentieth century British political observer James Bryce $(1912,128)$ wrote that midterm elections enable the voters "to express their approval or disapproval of [the president's] conduct by sending up another House of Representatives which may support or oppose the policy he has offered." President Woodrow Wilson, reflecting on the 1914 midterm election, commented that people "know that to vote against a democratic [sic] ticket is to vote indirectly against me" (Berg 2013, 344). Nearly a half-century later, political scientist V.O. Key $(1958,612)$ also placed the president at the heart of midterm campaign: "In truth, the President and his program create the central issue of the campaign, and the midterm election becomes in a sense a referendum on the conduct of the government by him and his party." These observations have received substantial empirical support from studies of both election outcomes and voter preferences that have shown public evaluations of the president's job performance to be a significant factor in midterm congressional elections. ${ }^{5}$

What is uncertain is why assessments of the president's job performance are so influential in midterm congressional elections. One possibility is that assessment of the president is a convenient voting cue. Campaigns for the U.S. House of Representatives do not generate the public or media interest evident in presidential, senatorial, and gubernatorial campaigns. Voters therefore operate with limited information about the candidates and their positions. With little known about the candidates, the voters look for related cues, accepting partisan affiliationeither shared with or opposite of the president—as proxy information about the candidate's own position (Popkin 1991, 213). Voters may not know much about the congressional candidates, but they know how they feel about the president. Or voting in midterm elections could be a

\footnotetext{
${ }^{3}$ Coleman (1997) argued that the 1994 Republican gains in the House of Representatives were only slightly larger than what would be expected, based on his findings that Republican presidents are advantaged - and Democratic presidents disadvantaged - in midterm congressional elections.

${ }^{4}$ Owens (1998) found Democratic incumbents' support of Clinton's legislative agenda not to affect their vote percentages.

${ }^{5}$ The list of macro-level studies of midterm congressional election outcomes is extensive. Among the more notable studies are Tufte (1975); Kernell (1977); Jacobson and Kernell (1983); Born (1986); Oppenheimer et al. (1986); Jacobson (1989); Marra and Ostrom (1989); Gaddie (1997); Campbell (1997b); Newman and Ostrom (2002). Notable among the studies of individual voter preferences in presidential elections are Piereson (1975); Hinckley (1980); Abramowitz (1980, 1985, 1995); Born (1986); Jacobson and Kernell (1990); and Nicholson and Segura (1999).
} 
product of displaced anger. Tufte $(1975,813)$ argues that with "no other targets available at the midterm, it is not unreasonable to expect that some voters opposed to the President might take out their dissatisfaction with the incumbent administration on the congressional candidates of the President's party." Not being able to vote against an unpopular president, the voters vent their frustration by voting against his party's congressional candidates.

The dynamic of the local campaign also could account for the election being a referendum on the president. As Jacobson $(2009$, 174) notes, "[ $\mathrm{t}]$ he connections between national issues and individual voting decisions are forged by the rhetoric of campaigns." Voters in a district may take aim on the president not merely out of convenience but because the congressional candidate of the opposition party attacks the president and the president's policies. Congressional elections are often characterized as local affairs, with emphasis on political characteristics of the district, local conditions, and the candidate's personal connections with the constituency (Herrnson 2016; Mann 1978; Mann and Wolfinger 1980; Wattenberg 1991). This follows former Speaker of the House Thomas P. O'Neill's (1994, xv-xvi) mantra that "all politics is local." But when candidates emphasize national issues in their campaign rhetoric, national issues and the local campaign dynamics converge to give greater weight to the former than would be felt otherwise, and the most prominent "national issue" of a midterm congressional election is presidential performance. Candidates make strategic decisions that guide their conduct and the allocation of resources (Burden 2004; Druckman, Kifer, and Parkin 2009; Lau and Pomper 2002; Sellers 1998; Skaperdas and Grofman 1995). Important choices include whether to focus on the candidate or the candidate's opponent and whether to emphasize the candidate's strengths or the opponent's weaknesses. For a midterm election, which strategy to follow hinges, at least in part, on the candidate's party affiliation and the popularity of the president in the district. Table 1 presents a schematic of how these factors become part of the campaign calculus.

\begin{tabular}{|c|c|c|}
\hline \multicolumn{2}{|c|}{ Table 1. Campaign Strategies Based on Party and President's Popularity } \\
\hline & \multicolumn{2}{|c|}{ Candidate's Political Party } \\
\hline President's Popularity & President's Party & Opposition Party \\
\hline High & Support the President & Local Focus \\
\hline Low & Local Focus & Attack the President \\
\hline
\end{tabular}

Candidates of the president's party will support the administration when the president's popularity is high but focus on local issues, such as service to the district and the candidates' qualifications for office, when the president's popularity is low. Candidates of the opposition party adopt contrasting strategies, drawing attention to the administration when the president is unpopular in the constituency and focusing on local concerns or personal traits when the president is popular. Low approval ratings in public opinion polls, difficulty in getting an economic package through Congress the year before, failure of health care reform during the election year, and questions about personal financial dealings set the stage for the 1994 midterm 
election to be a referendum on the Clinton presidency, but it remained for the candidates to take advantage of this situation at the local level.

The president becomes a focus of the local campaign if the opposition party-as an organization or through its candidate-criticizes the president and his policies or the opposition party characterizes the candidate of the president's party as a supporter or potential supporter of the president. There can be circumstances when the presidential party characterizes the opposition party candidate as an opponent or potential opponent of the president, but these are rare. ${ }^{6}$ The first two scenarios are the most likely since opposition party candidates have more to gain by attacking a president whose popularity has undoubtedly declined during his term than candidates of the president's party have by defending him. ${ }^{7}$ This reflects the impact of negativity in campaigns, as viewers respond more strongly to negative news (Smith and Searles 2014; Soroka and McAdams 2015), viewers are more likely to remember information from negative advertisements than from positive advertisements (Brians and Wattenberg 1996; Fridkin and Kenney 2004; Lau and Redlawsk 2005), and voters are motivated more by opposition to a candidate or officeholder than by support (Cover 1986; Kernell 1977; Lau 1982).

\section{Measuring Campaign Focus}

The key variable for this analysis is whether the district-level campaign for the House of Representatives emphasized the president and his policies. Information for all competitive House races - that is, those featuring both Democratic and Republican candidates in 1994-was examined and coded using a simple dichotomy: 1 if the Republican candidate made President Clinton a focus of the campaign at the district level and 0 if not. This measure does not reflect support for the president for the simple reason that few Democrats offered explicit defenses of the president. Additionally, the few districts featuring defenses of the president also featured Republican attacks on the president.

Two sources were used for identifying congressional campaigns having a presidential campaign focus. First, campaign advertisements available at the Julian P. Kanter Political Commercial Archive at the University of Oklahoma were viewed for messages that linked either the sponsoring candidate or opposing candidate with the president and/or the president's policies. No distinction was made between advertisements sponsored by candidates or by political parties as voters are unlikely to draw such distinctions and the requirement of the Bipartisan Campaign Finance Act that candidates explicitly identify themselves in advertisements they authorize was several years into the future. Opposition to the president was indicated by such acts as criticism of the president's policies, criticism of the incumbent

\footnotetext{
${ }^{6}$ An obvious example of this scenario was 1986, when Republican candidates sought to share in the glow of Ronald Reagan's high approval ratings.

${ }^{7}$ Brace and Hinckley (1992,31-38) demonstrate a "decay function" in presidential popularity, with the president's approval rating nearing its lowest point at or just before the midterm elections.
} 
Democrat for voting for the president policies, boasts by incumbent Republicans of having voted against the president's legislative program, and assertions that a Democratic challenger would be an ally or puppet of the president. Links to the president by the Republican candidate must be unambiguous: President Clinton by name or title must be mentioned explicitly; a word or phrase that clearly indicates the president (e.g., "the White House") must be used; or President Clinton or the White House pictured in the advertisement. One common advertising approach involved picturing the president and Democratic candidate together; another common approach had a photograph of the Democratic congressional candidate fade while a photograph of Clinton emerged.

The second source of information on campaigns is the descriptions of the campaign at the district level presented in Congressional Quarterly Weekly Report's election preview and postelection review. The following are examples of phrases used by Congressional Quarterly's correspondents in 1994 that resulted in the district being coded as featuring an attack on the president:

- “McIntosh's first ads criticized Clinton on crime, health care, welfare reform and his 1993 budget — and did not even mention Hogsett." (Indiana 2nd)

- "Hartzell has attacked Lowery for her support for Clinton on issues such as the deficitreduction bill and the crime bill." (New York 18th)

- “Thornberry ... labels Sarpalius a Clinton loyalist." (Texas 13th)

- "Salmon has aired an ad similar to those seen in other states, in which a computer 'morphs' a photograph of Blanchard into Clinton, indicating that Blanchard would be a consistent Clinton supporter." (Arizona 1st)

- "Kreidler was one of the Democrats chastised for voting for Clinton's budget in radio ads aired in selected districts last year by the Republican National Committee." (Washington 9th)

Each of these campaign descriptions reports the Republican candidate or Republican party drawing the voters' attention to the president, making Bill Clinton a focus of the district-level congressional campaign. A reporter's comment that the incumbent was a regular supporter of the president's legislative initiatives, or that the president was unpopular in the constituency is not sufficient for coding the district as having a presidential campaign focus. There must be an indication that President Clinton and/or his policies were explicitly part of the campaign message presented the Republican candidates or party.

This simple dichotomous measure of presidential campaign focus is not elaborate yet satisfies the needs of this inquiry. While undoubtedly there were districts not coded as possessing a presidential focus in which a candidate discussed the president and his policies in campaign speeches or advertisements, there is a significant qualitative difference between occasional mention and emphasis to a degree that makes the president a theme of paid political advertising 
or that warrants comment by national media. A shortcoming of this coding scheme is that it does not provide a scale of campaign intensity; this is due to differences in information available across congressional districts. For example, only one advertisement aired by Republican Terry Everett in Alabama's second district is archived, compared with more than a dozen by Republican Ron Lewis in Kentucky's second district. Nor is information available on the frequency particular advertisements were aired or if the advertisement was viewed across the district or in separate media markets. The simple measure nevertheless distinguishes between districts where the campaign focused extensively on the incumbent president and where it did not. Nonetheless, because of this limitation the analysis is constrained to the 192 House districts featuring candidates of both major parties for which district-level information is available through either the Kanter Archive or Congressional Quarterly's district-by-district analyses. Just over one half of the competitive districts are included in the sample. The sample is not randomly drawn and tilts slightly toward more competitive districts and open-seat districts at the expense of districts with Republican incumbents (Appendix B). Nonetheless, a majority of sample districts were won by the Republican candidate, reflecting the results of the election.

Despite the measurement limitations we can identify many contested districts featuring overt attacks on the administration by the Republican candidate and/or Republican Party and in patterns as would expected under the presidential referendum theory of midterm congressional elections. Figure 1 shows that attacks on Clinton were most frequent in districts where a Democratic incumbent sought reelection with three-fifths of Democratic incumbents being characterized as Clinton supporters. Such characterizations of the Democratic candidate appeared in open-seat contests as well but with notably less frequency. Only one-third of Republican incumbents thought it necessary to raise the specter of the Clinton presidency, undoubtedly because they were running in Republican-leaning districts and their reelections were near certainties. Similarly, Republican attacks on the president were more frequent in more competitive districts (Figure 2). Three-fifths of the districts where the victor's margin was less than ten percentage points featured attacks on the president, as compared to two-fifths of less competitive districts. The context of the campaign-incumbency and closeness of the electionset the stage for the local race being a Clinton referendum. 


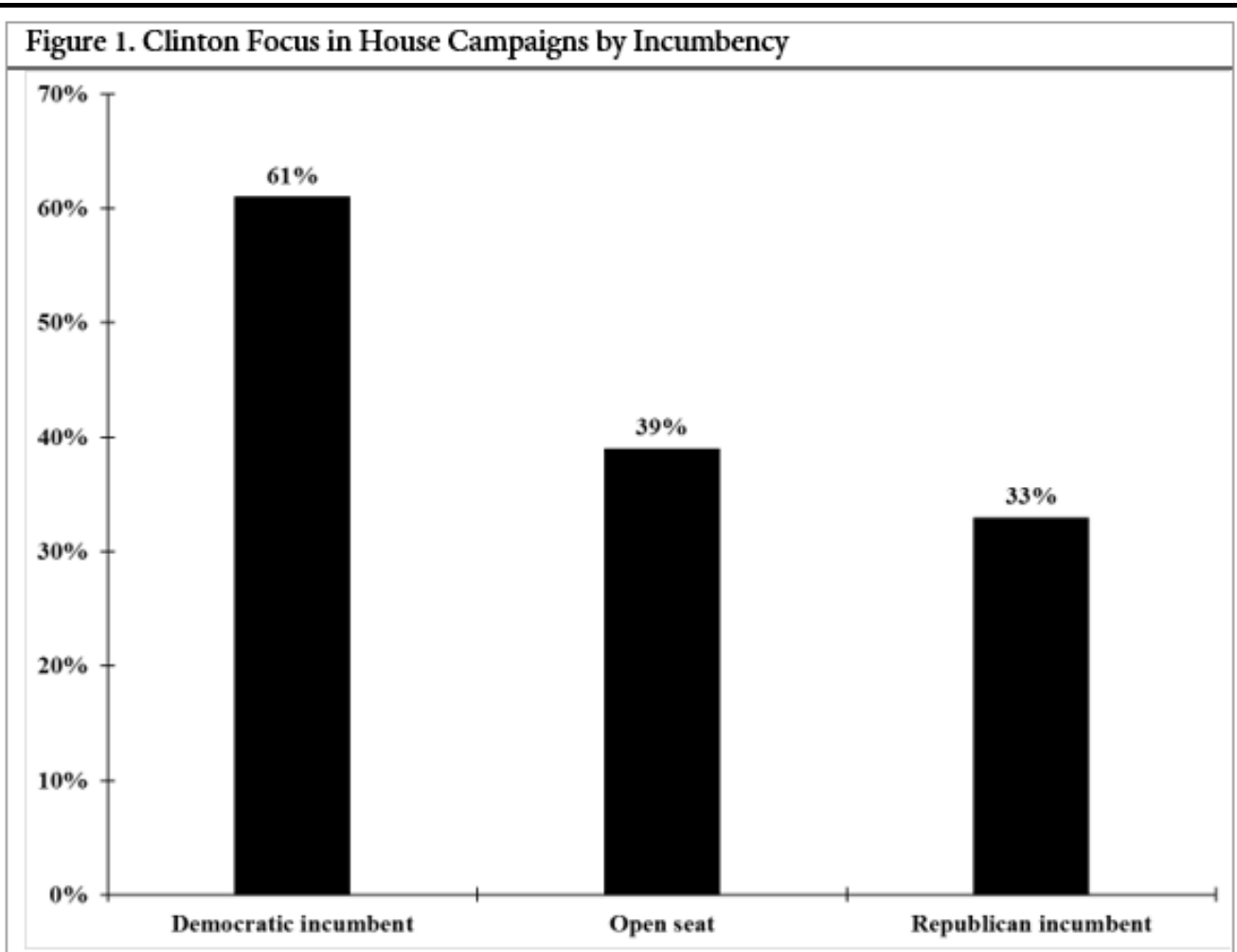

Figure 2. Clinton Focus in House Campaigns by Vote Margin

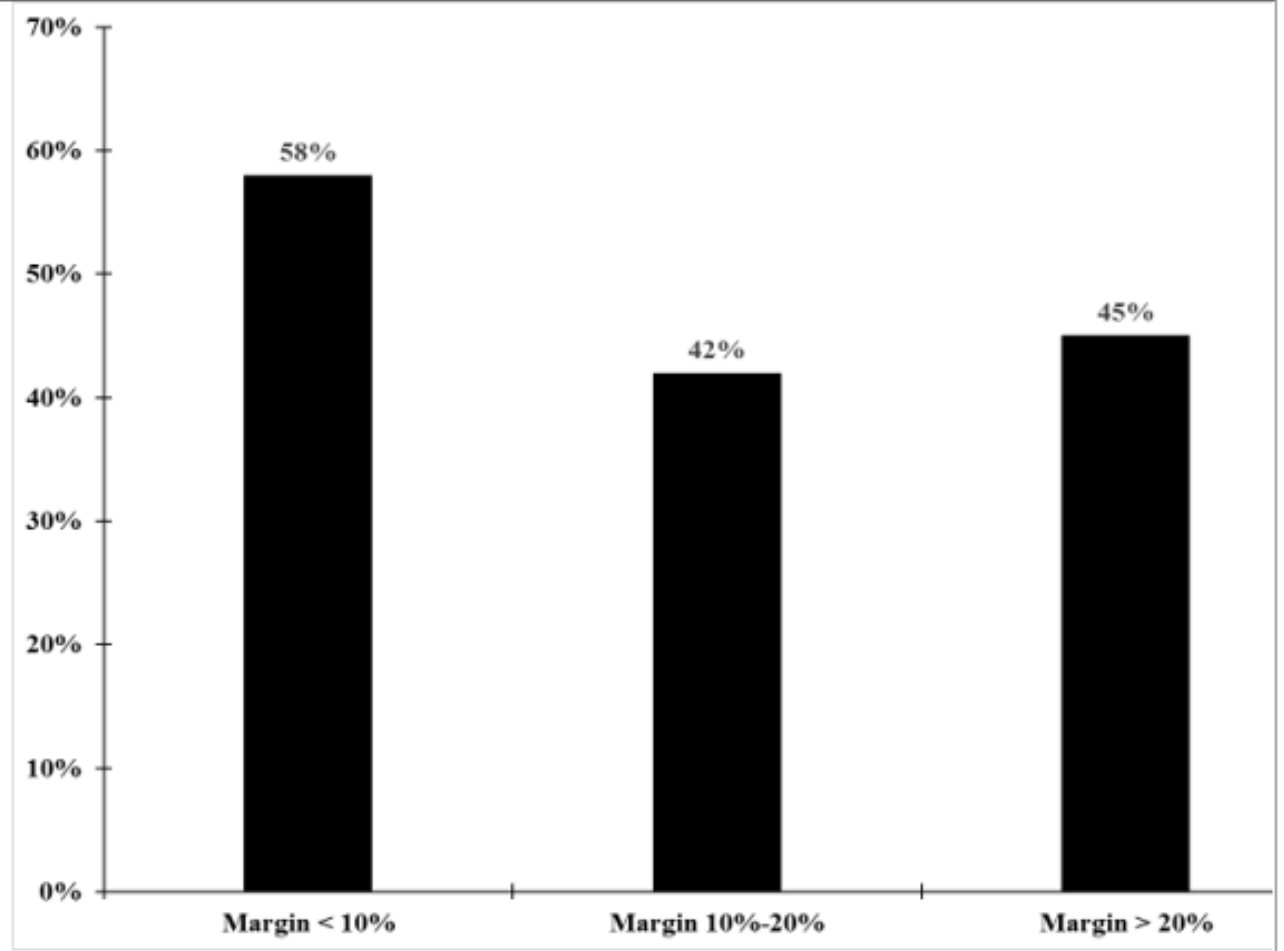


Effect of Targeting President Clinton

The campaign contextual data are merged with survey data from the 1994 American National Election Study to assess the impact of campaigns focusing on the administration and the conditional effects of presidential popularity. Two hypotheses are tested:

- $\mathrm{H}_{1}$ : Attacking the president in the constituency-level campaign decreases the probability of voting for the presidential party candidate for the House of Representatives.

- $\mathrm{H}_{2}$ : Making the president a focus of the constituency-level campaign increases the effect of evaluation of the president's performance on vote choice for the House of Representatives.

Other research has shown preference between major party candidates in midterm congressional elections to be a function of the voter's evaluation of the president's performance, the voter's partisan and ideological predispositions, and the presence of an incumbent seeking reelection (e.g., Abramowitz 1985 and 1995; Born 1986; Nicholson and Segura 1999; Pierson 1975). ${ }^{8}$ To assess the impact district-level campaigns drawing attention to the administration have on voters' decisions, a measure of campaign context and an interaction term between campaign context and presidential evaluation are added. These factors come together in a model of vote choice specified as:

$$
\mathrm{V}=\mathrm{b}_{0}+\mathrm{b}_{1} \mathrm{CF}+\mathrm{b}_{2} \mathrm{PE}+\mathrm{b}_{3}\left(\mathrm{CF}^{*} \mathrm{PE}\right)+\mathrm{b}_{4} \mathrm{PI}+\mathrm{b}_{5} \mathrm{ID}+\mathrm{b}_{6} \mathrm{IN}+\mathrm{e}
$$

where $\mathbf{V}$ is vote for United States representative in 1994, coded one if the respondent voted for the Democratic candidate and zero if for the Republican candidate; CF is Clinton focus, coded as one if Clinton was a focus of the campaign in the congressional district and zero if not; PE is presidential evaluation, measured by the feeling thermometer scale toward Clinton; and $\mathbf{C F}^{*} \mathbf{P E}$ represents the interaction of Clinton focus and presidential evaluations. The remaining factors serve as control variables reflecting political predispositions and district campaign characteristics:

\footnotetext{
${ }^{8}$ A component of the referendum theory of congressional elections is that voters respond to perceptions of economic conditions. Although economic variables commonly demonstrate statistically significant effects in aggregate models of midterm election outcomes, individual-level analyses provide little evidence of voters' assessments of personal financial situation and national economic conditions affecting vote choice. The model was estimated including variables for both perceptions of personal financial situation and national economy performance, but no statistically significant effects were identified. Additionally, while some analyses find spending by candidates to affect voters' decisions, our test of several measures of candidate spending showed no statistically significant effects on voter choice. Therefore, in the interest of parsimony, variables reflecting perceptions of personal financial condition, perceptions of economic performance and candidate spending are not included in this analysis.
} 
PI is party identification, coded as one if the respondent was an identifier with or leaner toward the Democratic party, zero if a pure independent, and negative one if an identifier with or leaner toward the Republican party; ID is ideological identification, measured as a scale ranging from +3 if extremely liberal to -3 if extremely conservative; IN is incumbency, coded as one if an incumbent Democrat sought reelection in the voter's district, zero if an open seat, and negative one if an incumbent Republican sought reelection; and e designates the error term. All coefficients are expected to be positive except that for campaign focus $\left(b_{1}\right)$, where a negative coefficient indicates that drawing attention to President Clinton decreased the probability of voting for the Democratic candidate.

Table 2 shows the logistic regression estimates for assessing the effects of campaign context on vote choice in the 1994 midterm congressional election. The left-hand column presents a base model of congressional election vote choice. Four-fifths of the cases are predicted correctly, the error in predicting the dependent variable is reduced substantially, and the control variables behave as expected: Democrats, liberals, and residents of districts with a Democratic incumbent seeking re-election were most likely to vote for the Democratic candidate in 1994. Also as expected, voters' assessments of Clinton's performance in office positively affected their choice between the Democratic or Republican candidate.

The coefficients in the right-hand column of Table 3 provide the tests of and support for our hypotheses that targeting the president influenced voter behavior in 1994. In short, controlling for political predispositions and incumbency, voters reacted to campaign messages regarding Clinton when casting their ballots for U.S. representative. The coefficient for Clinton focus is negative and statistically significant, indicating that drawing attention to President Clinton and his administration decreased the probability of individuals casting their ballots for the Democratic candidate. The effect of drawing attention to the president during the local congressional race is also evident from the interaction between campaign focus and presidential evaluation. The coefficient for the interaction term is larger than that for unconditioned presidential evaluation and statistically significant while the coefficient for unconditioned presidential evaluation is not statistically significant.

Clearly the Republican strategy of targeting the president reduced the probability of voting for the Democratic candidate and magnified the effect of voters' perception of Clinton. Candidates are more likely to concentrate on the opponents' issue positions in s competitive races (Herrnson 2016) and, as indicated above, candidates of the other political party are more likely to focus their policy-based attacks on the president and link their opponents to the policies of the administration. Negativity increases with the competitiveness of congressional elections and in 1994 the effect of negativity was to enhance the effect that evaluation of the president had on voters' decisions. 
Table 2. Effect of Campaign Focus on U.S. House Vote Choice in 1994

\begin{tabular}{|c|c|c|}
\hline Variable & Base Model & Referendum Model \\
\hline Clinton Campaign Focus & ---- & $\begin{array}{c}-1.498^{* * *} \\
(.564)\end{array}$ \\
\hline Presidential Evaluation & $\begin{array}{c}0.019^{* * *} \\
(.006)\end{array}$ & $\begin{array}{l}0.007 \\
(.007)\end{array}$ \\
\hline Interaction $\left(\mathrm{CF}^{*} \mathrm{PE}\right)$ & ---- & $\begin{array}{c}0.0125^{* *} \\
(.009)\end{array}$ \\
\hline Partisan Identification & $\begin{array}{c}1.031^{* * *} \\
(.156)\end{array}$ & $\begin{array}{c}1.027^{* * *} \\
(.156)\end{array}$ \\
\hline Ideological Identification & $\begin{array}{c}0.449^{* * *} \\
(.111)\end{array}$ & $\begin{array}{c}0.447^{* * *} \\
(.114)\end{array}$ \\
\hline Incumbency & $\begin{array}{c}0.651^{* * *} \\
(.164)\end{array}$ & $\begin{array}{c}0.662^{* * *} \\
(.166)\end{array}$ \\
\hline Constant & $\begin{array}{l}-1.064 \\
(.355)\end{array}$ & $\begin{array}{l}-.311 \\
(.421)\end{array}$ \\
\hline Model Chi-Square & 159.42 & 158.38 \\
\hline Pseudo $\mathrm{R}^{2}$ & 0.370 & 0.381 \\
\hline Cases predicted correctly & $81 \%$ & $82 \%$ \\
\hline Proportional reduction of error & 0.590 & 0.599 \\
\hline$N$ & 498 & 498 \\
\hline \multicolumn{3}{|c|}{$\begin{array}{l}\text { Dependent variable is vote for the U.S. House ( } 1=\text { Democrat, } 0=\text { Republican). Entries are logistic } \\
\text { regression coefficients with robust standard errors are in parentheses. } \\
p^{*}<.05 ; "{ }^{* *} p<.01 ;{ }^{* * *} p<.001 \text { (one-tailed tests) }\end{array}$} \\
\hline
\end{tabular}


American Review of Politics

Volume 37 Issue 1

\begin{tabular}{|c|c|c|c|c|}
\hline \multirow[b]{2}{*}{ Voter Characteristics } & \multirow[b]{2}{*}{ Campaign Context } & \multicolumn{3}{|c|}{ Incumbency Status } \\
\hline & & Democrat & Open & Republican \\
\hline \multirow{2}{*}{ Democrat, liberal } & Clinton not a campaign focus & 0.94 & 0.89 & 0.85 \\
\hline & Clinton a campaign focus & 0.96 & 0.92 & 0.85 \\
\hline \multirow{2}{*}{ Independent, moderate } & Clinton not a campaign focus & 0.66 & 0.5 & 0.34 \\
\hline & Clinton a campaign focus & 0.56 & 0.4 & 0.26 \\
\hline \multirow{2}{*}{ Republican, conservative } & Clinton not a campaign focus & 0.21 & 0.12 & 0.06 \\
\hline & Clinton a campaign focus & 0.11 & 0.06 & 0.03 \\
\hline
\end{tabular}

The importance of taking campaign context into account when assessing voting behavior in the 1994 midterm congressional elections is underscored when the probabilities of voting for the Democratic candidate are considered. For this exercise, individual voter characteristics (party identification and ideological identification), incumbency status, and campaign contextwhether the president is a focus of the local campaign - are manipulated to test the impact of presidential evaluation on vote choice under varying conditions. In calculating the probability of voting for the Democratic congressional candidate, the value of the presidential evaluation variable is the sample mean for the party identification category. ${ }^{9}$ The probabilities displayed in Table 3 indicate that a campaign drawing attention to President Clinton decreased an independent or Republican voter's probability of casting a ballot for the Democratic candidate for U.S. Representative. Only voters identifying themselves as Democrats or Republicans where a Republican incumbent sought reelection were immune to attacks on the president and his administration. In general, the differences in the probability of voting for the congressional candidate of the president's party are consistent with the notion that highlighting the administration in the campaign disadvantages candidates of the president's party.

Individual votes, when aggregated, produce election outcomes. A second way of considering the impact of targeting the president in campaign messages is to examine election results at the district level. For this, we define a linear model of election outcome specified as:

$$
\mathrm{D}_{94}=\mathrm{b}_{0}+\mathrm{b}_{1} \mathrm{CF}+\mathrm{b}_{2} \mathrm{PV}_{92}+\mathrm{b}_{3} \mathrm{PS}+\mathrm{b}_{4} \mathrm{DV}_{92}+\mathrm{b}_{5} \mathrm{IN}+\mathrm{b}_{6} \mathrm{CQ}+\mathrm{b}_{7} \mathrm{DE}+\mathrm{b}_{8} \mathrm{RE}+\mathrm{e}
$$

where the dependent variable $\mathbf{D}_{94}$ is measured in two ways. The first is Democratic percent of the two-party vote for United States representative in the district. The second measure of the dependent variable is Democratic win, a binary variable where 1 indicates a win by the Democratic

9 Among the survey respondents who voted in the 1994 congressional election, the mean score on the feeling thermometer for Democrats was 72.6, for independents was 43.8, and for Republicans was 31.2. 
candidate and 0 indicates a win by the Republican candidate. Among the independent variables,

CF is Clinton focus, coded as one if Clinton was a focus of the campaign in the district and zero if not; $\mathbf{P V}_{92}$ is presidential vote in 1992, measured as the percentage of the vote received by Bill Clinton; PS represents presidential support, the incumbent representative's support for the Clinton administration's position on four salient pieces of legislation considered during the $103^{\text {rd }}$ Congress; ${ }^{10} \mathbf{D V}_{92}$ is 1992 Democratic vote for U.S. representative in the district; IN is incumbency, coded as one if an incumbent Democrat sought reelection, zero if an open seat, and negative one if an incumbent Republican sought reelection; CQ is challenger quality, coded as one if the Democratic challenger had prior experience in elective office, zero if the challenger had no experience, zero if both challengers for an open seat had prior experience in elective office, and negative one if the Republican challenger had prior experience in elective office; DE is the natural $\log$ of the Democratic candidate's expenditures; $\mathbf{R E}$ is the natural $\log$ of the Republican candidate's expenditures; and e designates the error term. ${ }^{11}$ The coefficients for presidential vote $\left(\mathrm{b}_{2}\right)$, Democratic vote in $1992\left(b_{4}\right)$, incumbency $\left(b_{5}\right)$, challenger quality $\left(b_{6}\right)$, and Democratic candidate's expenditures $\left(b_{7}\right)$, are expected to be positive; coefficients for campaign focus $\left(b_{1}\right)$, presidential support $\left(b_{3}\right)$, and Republican candidate's expenditures $\left(b_{8}\right)$, are expected to be negative. The key, again, is the coefficient for campaign focus, which indicates that drawing attention to President Clinton decreases the Democratic candidate's vote percentage.

10 The votes used to construct this proportional scale are the Family and Medical Leave Act (House vote 22, 1993); the 1993 budget reconciliation (House vote 406, 1993); implementation of the North American Free Trade Agreement (House vote 575, 1993); and the Omnibus Crime Bill (House vote 416, 1994). In each instance, a "yea” vote supported the Clinton administration's position.

${ }^{11}$ This model is based on those used by Brady et al. (1996), Jacobson (1996), and Owens (1998). 
Table 4. Effect of Campaign Focus on Democratic Vote Percentage for U.S. House in 1994

\begin{tabular}{|c|c|c|}
\hline Variable & $\begin{array}{l}\text { Democratic } \\
\text { Percentage }\end{array}$ & Democratic Win \\
\hline Clinton campaign focus & $\begin{array}{c}-2.17^{* *} \\
(0.80)\end{array}$ & $\begin{array}{c}-1.58^{* *} \\
(0.59)\end{array}$ \\
\hline 1992 presidential vote & $\begin{array}{c}0.46^{* * *} \\
(0.07)\end{array}$ & $\begin{array}{c}0.16^{* * *} \\
(0.04)\end{array}$ \\
\hline Presidential support & $\begin{array}{l}-0.04^{*} \\
(0.02)\end{array}$ & $\begin{array}{c}-0.01 \\
(0.01)\end{array}$ \\
\hline 1992 Democratic vote for House & $\begin{array}{c}0.10^{*} \\
(0.05)\end{array}$ & $\begin{array}{c}0.01 \\
(0.02)\end{array}$ \\
\hline Incumbency & $\begin{array}{c}7.33^{* * *} \\
(0.86)\end{array}$ & $\begin{array}{c}3.06^{* * *} \\
(0.67)\end{array}$ \\
\hline Challenger quality & $\begin{array}{c}2.17^{* * *} \\
(0.69)\end{array}$ & $\begin{array}{c}0.80 \\
(0.52)\end{array}$ \\
\hline Democratic candidate's expenditures & $\begin{array}{c}1.03^{* * *} \\
(0.28)\end{array}$ & $\begin{array}{l}-0.18 \\
(0.13)\end{array}$ \\
\hline Republican candidate's expenditures & $\begin{array}{c}-1.57^{* * *} \\
(0.70)\end{array}$ & $\begin{array}{l}-0.48 \\
(.050)\end{array}$ \\
\hline Constant & $\begin{array}{c}30.89 \\
(10.39)\end{array}$ & $\begin{array}{c}0.46 \\
(6.47)\end{array}$ \\
\hline F / Wald chi-square & $61.39^{* * *}$ & $59.49^{* * *}$ \\
\hline $\mathrm{R}^{2} /$ pseudo- $\mathrm{R}^{2}$ & 0.732 & 0.506 \\
\hline Root MSE / Cases correctly classified & 5.3 & $86 \%$ \\
\hline Proportional reduction of error & ----- & 0.671 \\
\hline$N$ & 192 & 192 \\
\hline \multicolumn{3}{|c|}{$\begin{array}{l}\text { Dependent variables are the Democratic percentage of the two-party vote for U.S. House (left-hand } \\
\text { column) and outcome of the election for the U.S. House ( } 1=\text { Democrat won, } 0=\text { Republican won; right- } \\
\text { hand column). Entries are OLS and logistic regression coefficients with robust standard errors are in } \\
\text { parentheses. } \\
{ }^{*} p<.05 ; "{ }^{*}<<.01 ; " * *<<.001 \text { (one-tailed tests) }\end{array}$} \\
\hline
\end{tabular}


The results of the ordinary least squares regression appear in the left-hand column of Table 4. All regression coefficients are statistically significant at the .05 level (or better) and are in the hypothesized direction. What is important to note is the coefficient for presidential campaign focus. The regression coefficient indicates that, other things being equal, making President Clinton the focus of local campaign rhetoric decreased the vote for the Democratic candidate by $2.2 \%$. The importance of this number is evident when we consider what $2.2 \%$ of the vote meant to Democratic candidates in hotly contested races. In 1994, there were 20 House districts in which the Democratic candidate losing that $2.2 \%$ of the vote was the difference between a Democratic victory and a Republican victory. Had the Democratic candidate prevailed in each of these districts, Democrats would have retained control of the House of Representatives and the 1994 midterm would not have been heralded as unusually detrimental to the president's party. The Republican Revolution would have stalled.

The right-hand column of Table 4 presents the results of the logic regression for Democratic win. The conclusions are similar, as three factors significantly impacted the outcome in the district: Clinton's vote percentage in the 1992 presidential election; whether a Democrat or Republican was seeking reelection; and whether the Republican candidate made Clinton a focus of the campaign at the district level. This highlights once again the importance as the probability of Democratic candidate decreased when the Republican targeted the president in campaign messages.

\section{Discussion}

Following the 1994 midterm election, Newt Gingrich, the prospective Speaker of the House, proclaimed the election results as proof that Americans wanted the Contract with America enacted (Dowd 1994). But the more common perspective was expressed by Senate Republican leader Robert Dole, who characterized the election as "a vote of no confidence" in President Clinton's agenda (Balz 1994b). Dole's interpretation seems more accurate, as the analysis presented here demonstrates the effects of the Republican campaign strategy of attacking the president and linking Democratic candidates to the president's agenda on voters' decisions and district-level outcomes.

Former Speaker Tip O’Neill's often-repeated axiom that "all politics is local” runs counter to the notion of national campaigns lying at the heart of the presidential referendum theory of midterm congressional elections, but this analysis supports O'Neill by demonstrating the importance of the local campaign dynamics. Candidates transform the national issue of a president's performance into a local issue by their choice of a campaign theme. The 1994 congressional election illustrates how making the president a focus of the campaign within the constituency can pay significant dividends. The probability of an individual voter casting a ballot for the Democratic congressional candidate decreased when President Clinton became the focus of the local campaign. Additionally, the impact of President Clinton's popularity on vote choice increased when the local Republican candidate cast the election as a presidential referendum. It 
is unmistakable that highlighting the president's job performance and his policies at the district level transformed the midterm congressional election into a presidential referendum.

Kahn and Kenney $(1997,1201)$ note that "the political actors who are successful in shaping the content of campaigns determine how the candidates will be assessed." Casting the 1994 midterm election as a choice between a supporter and an opponent of Bill Clinton amplified the role that evaluation of the president plays as a voting cue and, by extension, the presidential referendum effect of the midterm election. The positive effects of the Contract with America can be debated, but unquestionably a key element of congressional Republicans' 1994 campaign strategy was the decision to frame the campaign as a referendum on the presidency of Bill Clinton. And just as unquestionably, this strategy was successful in drawing votes of citizens dissatisfied with the Clinton presidency away from Democratic candidates for Congress.

The lessons of the 1994 congressional election have not be lost on Democratic and Republican candidates. In 2006, Democratic candidates attacked the policies of President George W. Bush concerning Iraq in a manner reminiscent of the 1994 campaign and with great effect; Democrats gained control of the House and Senate for the first time in twelve years. Four years later, Republicans took back the House, at least in part, by campaigning aggressively against President Barack Obama and his signature domestic policy program, the Patient Protection and Affordable Care Act, often dubbed "Obamacare." Obama won re-election in 2012 but two years hence was again the target of Republicans' midterm campaign attacks, an election Washington Post reporters Philip Rucker and Robert Costa described the 2014 in a manner reminiscent of their colleague David Broder's description of the midterm campaign twenty years before: "From the outset of the campaign, Republicans had a simple plan: Don't make mistakes, and make it all about Obama, Obama, Obama” (Rucker and Costa 2014). Republicans in that election retained their hold on the House of Representatives and added control of the Senate despite the president's efforts to defend his legacy.

Discussions of the 2018 midterm congressional election as a referendum on Donald Trump's presidency began shortly after his inauguration. W riting early in midterm year, media commentator Juan Williams (2018) commented that "Trump is too big. The election will be a referendum on him." Political observers found evidence both in public opinion polls and in the results of eight special elections to the House held during Trump's first two years. These races, with Democratic candidates emphasizing opposition to the president and Republican candidates faring worse than in previous elections, set the stage for another change in party control as Democrats won a majority of seats in the November election.

Each election year presents a different set of circumstances regarding the president's popular standing, saliency of issues, and the dynamic between the White House and Capitol Hill. The conceptualizations of elections to the House of Representatives as referenda on the president and as local affairs are not as much at odds as they might appear. As the 1994 election demonstrated, the referendum nature of the midterm election is magnified when the local 
campaign dynamic focuses on the occupant of the Oval Office.

\section{Acknowledgements}

This research was supported by the Congressional Research Grants program of The Dirksen Congressional Center, whose generosity is greatly appreciated. The reviewers for The American Review of Politics are also thanks for their helpful comments. The survey data used in this analysis were collected by the Center for Political Studies at the University of Michigan and made available through the Inter-University Consortium for Political and Social Research. Campaign advertisements were made available by the Julian P. Kanter Political Commercial Archive at the University of Oklahoma. These institutions bear no responsibility for the analysis and interpretations presented here. 


\section{Bibliography}

Abramson, Paul R., John H. Aldrich, and David W. Rohde. 1995. Change and Continuity in the 1992 Elections rev. ed. Washington, DC: CQ Press.

Abramowitz, Alan I. 1980. "A Comparison of Voting for U.S. Senator and Representative in 1978.” American Political Science Review 74 (September): 633-640.

Abramowitz, Alan I. 1984. "National Issues, Strategic Politicians, and Voting Behavior in the 1980 and 1982 Congressional Elections." American Journal of Political Science 28 (November): 710-721.

Abramowitz, Alan I. 1985. "Economic Conditions, Presidential Popularity, and Voting Behavior in Midterm Congressional Elections." Journal of Politics 47 (February): 31-43.

Abramowitz, Alan I. 1995. "The End of the Democratic Era? 1994 and the Future of Congressional Election Research." Political Research Quarterly 48 (December): 873889.

Balz, Dan. 1994a. "Party Controls Both Houses for First Time Since '50s." Washington Post, November 9, A 1.

Balz, Dan. 1994b. “Clinton, GOP Leaders Offer Cooperation.” Washington Post, November 10 , p. A1.

Berg, A. Scott. 2013. Wilson. New York: G.P. Putnam's Sons.

Berke, Richard. 1994. "Democratic Mainstays Ousted in Big Upsets around the Nation.” New York Times, November 9, p. A1.

Born, Richard. 1986. "Strategic Politicians and Unresponsive Voters." American Political Science Review 80 (June): 599-612.

Brace, Paul, and Barbara Hinckley. 1992. Follow the Leader: Opinion Polls and the Modern Presidency. New York: Basic Books.

Brady, David W., John F. Cogan, Brian J. Gaines, and Douglas Rivers. 1996. "The Perils of Presidential Support: How the Republicans Took the House in the 1994 Midterm Elections." Political Behavior 18 (No. 4): 357-359. 
Brians, Craig L., and Martin P. Wattenberg. 1996. "Campaign Issue Knowledge and Salience: Comparing Reception from TV Commercials, TV News, and Newspapers.” American Journal of Political Science 40 (February): 172-193.

Broder, David S. 1994a. “Anti-Clinton Platform.” Washington Post, September 19, p. C9.

Broder, David S. 1994b. “GOP House Party.” Washington Post, September 28, 1994, p. A23.

Broder, David S. 1994c. "Naked Punditry." Washington Post, November 6, 1994, p. C1.

Bryce, James. 1912. The American Commonwealth. New York: Macmillan.

Burden, Barry C. 2004. "Candidate Positioning in U.S. Congressional Elections." British Journal of Political Science 34 (May): 211-227.

Campbell, James E. 1997a. “The Presidential Pulse and the 1994 Midterm Congressional Election." Journal of Politics 59 (August): 830-857.

Campbell, James E. 1997b. The Presidential Pulse of Congressional Elections. Lexington: University Press of Kentucky.

Cillizza, Chris. 2014. “28 Words That Democrats Really Wish President Obama Didn't Say Today." The Washington Post, October 2 (www.washingtonpost.com/news/thefix/wp/2014/10/02/28-words-that-democrats-really-wish-president-obama-didnt-saytoday).

Clinton, Bill. 2004. My Life. New York: Alfred A. Knopf.

Coleman, John J. 1997. “The Importance of Being Republican: Forecasting Party Fortunes in House Midterm Elections.” Journal of Politics 59 (May): 497-519.

Cover, Albert D. 1986. "Presidential Evaluations and Voting for Congress." American Journal of Political Science 30 (November): 786-801.

Dowd, Maureen. 1994. "Vengeful Glee (and Sweetness) at Gingrich’s Victory Party.” New York Times, November 9, p. B2.

Druckman, James N., Martin J. Kifer, and Michael Parkin. 2009. "Campaign Communications in U.S. Congressional Elections.” American Political Science Review 103 (September): 343-366. 
Fridkin, Kim Leslie, and Patrick J. Kenney. 2004. "Do Negative Messages Work? The Impact of Negativity on Citizens' Evaluations of Candidates." American Politics Research 32 (September): 570-605.

Gaddie, Ronald Keith. 1997. “Congressional Seat Swings: Revisiting Exposure in House Elections." Political Research Quarterly 50 (September): 699-710.

Herrnson, Paul S. 2016. Congressional Elections: Campaigning at Home and in Washington $7^{\text {th }}$ ed. Thousand Oaks, CA: CQ Press.

Hinckley, Barbara. 1980. “The American Voter in Congressional Elections.” American Political Science Review_74 (September): 641-650.

Jacobson, Gary C. 1989. "Strategic Politicians and the Dynamics of U.S. House Elections, 1946-86." American Political Science Review 83 (September): 773-793.

Jacobson, Gary C. 1996. “The 1994 House Elections in Perspective.” Political Science Quarterly 111 (Summer): 203-223.

Jacobson, Gary C. 2009. The Politics of Congressional Elections $7^{\text {th }}$ ed. New York: Pearson Longman.

Jacobson, Gary C., and Samuel Kernell. 1983. Strategy and Choice in Congressional Elections. New Haven: Yale University Press.

Jacobson, Gary C., and Samuel Kernell. 1990. "National Forces in the 1986 U.S. House Elections.” Legislative Studies Quarterly 15 (February): 65-87.

Kahn, Kim Fridkin, and Patrick J. Kenney. 1997. "A Model of Candidate Evaluations in Senate Elections: The Impact of Campaign Intensity." Journal of Politics 59 (November): 1173-1205.

Kernell, Samuel. 1977. "Presidential Popularity and Negative Voting: An Alternative Explanation of the Midterm Congressional Decline of the President's Party." American Political Science Review 71 (March): 44-66.

Key, V.O., Jr. 1958. Politics, Parties, and Pressure Groups $4^{\text {th }}$ ed. New York: Crowell.

Lau, Richard R. 1982. "Negativity in Political Perceptions." Political Behavior 4 (No. 4): 353378. 
Lau, Richard R., and Gerald M. Pomper. 2002. "Effectiveness of Negative Campaigning in U.S. Senate Elections.” American Journal of Political Science 46 (February): 47-66.

Lau, Richard R., and David R. Redlawsk. 2006. How Voters Decide: Information Processing during Election Campaigns. New York: Cambridge University Press.

Mann, Thomas E. 1978. Unsafe at Any Margin: Interpreting Congressional Elections. Washington, DC: American Enterprise Institute.

Mann, Thomas E., and Raymond E. Wolfinger. 1980. "Candidates and Parties in Congressional Elections." American Political Science Review 74 (September): 617-632.

Marra, Robin F., and Charles W. Ostrom, Jr. 1989. "Explaining Seat Change in the U.S. House of Representatives, 1950-1986." American Journal of Political Science 33 (August): 541-569.

Newman, Brian, and Charles W. Ostrom, Jr. 2002. "Explaining Seat Changes in the U.S. House of Representatives, 1950-98.” Legislative Studies Quarterly 27 (August): 383405.

Nicholson, Stephen P., and Gary M. Segura. 1999. "Midterm Elections and Divided Government." Political Research Quarterly 52 (September): 609-629.

O’Neill, Tip, with Gary Hymel. 1994. All Politics Is Local and Other Rules of the Game. New York: Times Books.

Oppenheimer, Bruce I., James A. Stimson, and Richard W. Waterman. 1986. "Interpreting U.S. Congressional Elections: The Exposure Thesis." Legislative Studies Quarterly 11 (May): 227-247.

Owens, John E. 1998. “The Importance of Candidate Characteristics and Local Political Conditions in the 1994 US Mid-term Elections." Political Studies 46: 766-776.

Pierson, James E. 1975. "Presidential Popularity and Midterm Voting at Different Electoral Levels." American Journal of Political Science 19 (November): 683-694.

Popkin, Samuel L. 1991. The Reasoning Voter: Communication and Persuasion in Presidential Campaigns. Chicago: University of Chicago Press. 
Rucker, Philip, and Robert Costa. 2014. "Battle for the Senate: How the GOP Did It." Washington Post, November 5. www.washingtonpost.com/politics/battle-for-thesenate-how-thegop-did-it/2014/11/04/a8df6f7a-62c7-11e4-bb144cfea1e742d5_story.html, accessed December 13, 2017.

Safire, William. 1994. "No Nyah-Nyah.” New York Times, November 10, p. A35.

Sellers, Patrick J. 1998. "Strategy and Background in Congressional Campaigns.” American Political Science Review 92 (March): 159-171.

Skaperdas, Stergios, and Bernard Grofman. 1995. “Modeling Negative Campaigning.” American Political Science Review 89 (March): 49-61.

Smith, Glen, and Kathleen Searles. 2014. "Who Let the (Attack) Dogs Out? New Evidence for Partisan Media Effects." Public Opinion Quarterly 78 (Spring): 71-99.

Soroka, Stuart, and Stephen McAdams. 2015. “News, Politics, and Negativity.” Political Communication 32 (\#1): 1-22.

Stanley, Harold W., and Richard G. Niemi. 2013. Vital Statistics on American Politics, 20132014. Washington, DC: CQ Press.

Tufte, Edward R. 1975. "Determinants of the Outcomes of Midterm Congressional Elections.” American Political Science Review 69 (September): 812-826.

Wattenberg, Martin P. 1991. The Rise of Candidate-Centered Politics. Cambridge: Harvard University Press.

Williams, Juan. 2018. "Midterms will be referendum on Trump," The Hill, May 28. URL: http://thehill.com/opinion/white-house/389563-juan-williams-midterms-will-bereferendum-on-trump (accessed July 3, 2018). 
Appendix A: District Coding

The following congressional districts featured contested elections for U.S. Representative in 1994 and were coded as having a presidential campaign focus to the local campaign. Districts included in the American National Election Study sample are in italics:

3rd Alabama, 2nd Arizona, 6th Arizona, 1st Arkansas, 2nd Arkansas, 4th Arkansas, 3rd California, 4th California, 6th California, 19th California, 36th California, 49th California, 5th Florida, 15th Florida, 3rd Georgia, 7th Georgia, 8th Georgia, 10th Georgia, 1st Idaho, 5th Illinois, 11 th Illinois, 19th Illinois, 1st Indiana, 2nd Indiana, 3rd Indiana, 4th Indiana, 5th Indiana, 8th Indiana, 10th Indiana, 4th Kansas, 1st Kentucky, 2nd Kentucky, 3rd Kentucky, 2nd Maryland, 6th Maryland, 6th Massachusetts, 1st Michigan, 12th Michigan, 2nd Minnesota, 6th Minnesota, 7th Minnesota, 1st Mississippi, 8th Missouri, AL Montana, 1st Nebraska, 2nd Nebraska, 1st Nevada, 2nd New Hampshire, 6th New Jersey, 8th New Jersey, 1st New York, 13th New York, 14th New York, 18th New York, 26th New York, 27th New York, 28th New York, 2nd North Carolina, 3rd North Carolina, 5th North Carolina, 11 th North Carolina, AL North Dakota, 1st Ohio, 6th Ohio, 14th Ohio, 19th Ohio, 1st Oklahoma, 2nd Oklahoma, 6th Oklahoma, 5th Oregon, 13th Pennsylvania, 3rd South Carolina, AL South Dakota, 3rd Tennessee, 6th Tennessee, 7th Tennessee, 1st Texas, 9th Texas, 10th Texas, 13th Texas, 24th Texas, 2nd Utah, 1st Virginia, 2nd Virginia, 4th Virginia, 9th Virginia, 11th Virginia, 1st Washington, 4th Washington, 5th Washington, 9th Washington, 2nd West Virginia, 1st Wisconsin, 4th Wisconsin, AL Wyoming. 


\section{Appendix B: Sample Assessment}

"Competitive districts" are the U.S. House of Representatives districts featuring both a Democratic and Republican candidate in the 1994 general election. Column totals might not sum to $100 \%$ because of rounding error.

\begin{tabular}{|clc|}
\hline Electoral margin: & Sample & Competitive districts \\
\hline Margin $<10 \%$ & $42 \%$ & $23 \%$ \\
\hline Margin $10 \%-20 \%$ & $28 \%$ & $19 \%$ \\
\hline Margin $>20 \%$ & $30 \%$ & 383 \\
\hline$N$ & 192 & \\
\hline Incumbency: & & Competitive districts \\
\hline Democratic incumbent & Sample & $55 \%$ \\
\hline Open seat & $54 \%$ & $14 \%$ \\
\hline Republican incumbent & $24 \%$ & $32 \%$ \\
\hline$N$ & $22 \%$ & 383 \\
\hline & 192 & \\
\hline Victorious candidate: & & $49 \%$ \\
\hline Democrat & Sample & Competitive districts \\
\hline Republican & $43 \%$ & $51 \%$ \\
\hline$N$ & $57 \%$ & 383 \\
\hline
\end{tabular}

